\title{
The Influence of Mathematics Teachers in the development of Entrepreneurial Skills among Secondary School Students in Makurdi Metropolice, Benue State, Nigeria
}

\author{
Clement O. Iji Ph.D \& Augustine A. Adoghe \\ Department of Science Education College of Agricultural and Science Education University of Agriculture, \\ Makurdi Benue State, Nigeria
}

\begin{abstract}
The level of unemployment in the country is becoming alarming. To reduce, this, government decided to introduce entrepreneurial study in the educational system of the country. This study was therefore aimed at ascertaining the extent to which the teaching of Mathematics by the mathematics teacher influenced the development of entrepreneurial skills in secondary school students. It was carried out in Makurdi Metropolice of Benue State, Nigeria. It adopted an expo-fact research design and population consisted of all the mathematics teachers in the 55 secondary schools in Makurdi metropolice. Four research questions were asked and answered using descriptive statistic of mean and standard deviation. Instrument for data collection was a four point questionnaire called Mathematics teacher Entrepreneurship Questionnaire (MTEQ). The study found among other things that entrepreneurial skills that could be developed in secondary schools students by the mathematics teacher through the teaching of Mathematics include: creative thinking, communication, persistency, problem-solving, aesthetic as well as constructive skills. It then recommended that Mathematics teachers should make concerted effort to improvise instructional materials to help in facilitating the development of entrepreneurial skills in secondary schools among others. Appropriate conclusions were equally made.
\end{abstract}

Keywords: Mathematics Teachers, Development, Entrepreneurial Skills, Secondary School Students, Teaching, Mathematics.

\section{Introduction}

It has been rightly observed that every good building begins with a foundation. The strength of such a building will ultimately be determined by the strength of the foundation Osafehinti (1990) and Odili (2006) opine that mathematics remains the key foundation to the building of science, technology and economic buoyancy. It has equally been generally observed that Mathematics and Science provide the basis for any country's economics emancipation and therefore, cannot be totally separated from the pace of its development Odili (2006) again states that mathematics cannot be separated from economic emancipation of any nation because of its wide and practical application in all human endeavour.

Aminu(1995) had earlier posited that mathematics is the essential nutrient for though and logical reasoning that metamorphosis into progress. This view emanated from Osafehinti(1990) who had observed that the learning of mathematics in school serves as a basic preparation for adult life. In his view, the acquisition of skills and understanding of arithmetical computation and its application to the solution of everyday problem remains a primary pursuit.

One of the national goals of education (Federal Republic of Nigeria (FRN), 2004) is the building of a great and dynamic economy through the inculcation of the right type of education for the survival of the individual and the Nigerian society. National development in terms of entrepreneurship cannot be achieved without the knowledge and use of mathematics. Entrepreneurs are not only essential to the growth and development of a country but remain the bedrock of its economic buoyancy. Our classroom in secondary schools are filled with students who will one day be leaders of business empires bank managers and proprietors of investments. These potential business magnates were sent to secondary schools by their parents and guardians with the hope that the potentials and skills they possess might be refined by the teachers they were entrusted to, foremost among these teachers is the mathematics teacher. This reality is pointed to the fact that every student is compulsorily made to study mathematics in the school. The degree to which these hopes are realized will be evidenced by the degree to which these potentials and skills are developed and sharpened by the mathematics teacher.

In the business world, for instance, one finds the use of mathematics in areas like budgeting, client billing and accounting, construction of life tables, premium rates, equity, ruin theory, discounted cash flow and banking. Mathematics helps the ordinary citizen to compare and estimate values of articles, determines prices of food stuff to mention but a few. Both the ordinary citizen and the entrepreneur need certain degree of 
competency in basic mathematics for the purpose of day-to-day running of businesses, management and control of money, interpreting of mathematical graphs and charts as well as general logical thinking.

Similarly, the entrepreneur is also considered as an economy builder. Tyolumun and Kwaghfan (2007) describe entrepreneurship as the engine and vital force in the economic development process of any nation. Indeed, no nation can be considered to be economically buoyant without the presence of entrepreneurial powers. As important as the entrepreneur may be to the economic development of a nation, one must not forget that the skills necessary for the survival and success in the entrepreneurial world are shaped and developed by individuals who through teaching and instruction, graduate the potential entrepreneur through a process.

As important as mathematics is to the world economy, one cannot engage in the discourse of the relevance of the subject to the business individual or entrepreneur without mentioning the 'bridge' between the subject and the potential entrepreneur, the mathematics teacher. Indeed, the mathematics teacher is saddle with the responsibility of developing in the students, skills necessary for proficiency in the business climate of the world. These skills which may be referred to as entrepreneurial skills, are vital to the economic growth of a nation and are sharpened through the instrumentality of mathematics by the mathematics teacher. The mathematics teacher therefore, is as relevant as the subject itself in the building and development of individual and the nation at large. In this regard, it is important for us to understand that what affects the mathematics teacher invariably affect the students of mathematics, and consequently, the development of skills necessary for a successful day-to-day living of the students in a wider world. The mathematics teacher is daily surrounded by budding professionals, specialists and entrepreneurs in his/her class. How he/she competently uses mathematics as a tool to affect the skills needed for their future career is most vital. If he/she fails, potential nation builders are lost. His/her success in the classroom becomes the emergence of a strong and viable nation-through the development of national economy, science and technology. With the foregoing in mind, it calls for a well trained and skillful mathematics teachers who will carryout the business of teaching and learning of mathematics in the nation's secondary schools. Osafehenti (1990). Therefore, explains that the learning of mathematics in schools represents the basic preparation for adult life and a gateway to a vast array of career choices. This therefore, revealed the fact that competency in mathematics is essential for the preparation of highly skilled personnel required by industries, business organizations, science and technology. The competency and the use of skills however, are built on a sound mathematics education developed through the tutelage of the mathematics teachers. Some of these students as have already been observed would emerge as the entrepreneurs, captains of industries and other professionals.

Tyolumun and Kwaghfan (2007) state that entrepreneurship is a process of identifying, developing and exploring opportunities with a view to creating a new venture of enterprise. For Nickles and Mchugh(2002) entrepreneurship means accepting the risk of starting and running a business while for Koontz, O.Donell and Weihinch (1980) an entrepreneur is a person who sees a business opportunity, obtains the needed capital, posses the necessary skills to put together an operation successfully and has the willingness to take a personal risk of success or failure. So far, it is quiet obvious that the acquisition of necessary skills is a sin-qua-non for a successful entrepreneur. Houston and Muholland (2003); and Tyolumun \& Kwaghfan (2007) identified such skills to include: communication skill, investigative skill, creative thinking skill, organizational skill, problemsolving skill, decision making skill, time management skill, constructive skill, persistency skill and aesthetic skill. How these skills are developed in the students is of great concern to the mathematics teacher. The main purpose of this study therefore, was to find out entrepreneurial skills that could be developed in secondary school students due to the teaching of mathematics by mathematics teachers. Specifically the study was to:

(a) Identify entrepreneurial skills that could be developed in the students through the

teaching of mathematics by the mathematics teachers

(b) Find out how mathematics teacher's methods of teaching mathematics affect the development of entrepreneurial skills in the students.

(c) Find out how the use of instructional materials by the mathematics teacher affects the development of entrepreneurial skills in the students

(d) Find out whether mathematics teacher's attitude to the teaching of mathematics affects the development of entrepreneurial skills in the students.

\section{Research Questions}

The following research questions were asked during the course of this study:

1. What are the entrepreneurial skills developed in the secondary school students by the mathematics teachers through the teaching of mathematics?

2. To what extent do mathematics teachers' methods of teaching mathematics affect the development of entrepreneurial skills in the secondary school students?

3. To what extent is the use of instructional materials by the mathematics teacher affect the development of entrepreneurial skills in the secondary school students? 
4. To what extent do mathematics teachers' attitudes toward the teaching of mathematics affect the development of entrepreneurial skills in the secondary school students?

\section{Methodology}

The research design adopted for this study was an ex-post facto design. Ex-post facto research design is a research in which the independent variable has already occurred and the researcher concerns him/herself with observing the possible relationship and effect on the dependent variable. It is a research design suitable for an after effect event. The design was therefore adopted because the searchers have no control over the variables of interest. The area of this study was makurdi metropolice of Benue state, Nigeria. Makurdi is the headquarters of Benue state and has River Benue as one of its primary geographical feature. Population of study consisted of all mathematics teachers insenior secondary schools within Makurdi metropolice. The instrument of study was a structured questionnaire called Mathematics Entrepreneurial Skill Questionnaire (MESQ). It was a four point scale of strongly agree, agree, disagree and strongly disagree, weighted 4, 3,2, 1 respectively for positively cued items and 1.2,3,4 for negatively cued items. This instrument under went face and content validation from experts in mathematics education and measurement and evaluation. Data collected and collated was analysed using descriptive statistic of mean and standard deviation. To arrive at a decision a mean of 2.50 and above for an item cued positively is considered accepted and otherwise for negatively cued.

\section{Result}

The result of this study is presented according to the research questions asked.

\section{Research Question 1}

What are the entrepreneurial skills developed in the secondary school students by the mathematics teacher through the teaching of mathematics?

The answer to this research question is presented in table 1

Table1: Mean rating and Standard Deviation of Entrepreneurial Skills Developed in Secondary Schools Students by Mathematics teachers.

\begin{tabular}{|c|c|c|c|c|c|}
\hline s/no & items & $X$ & SD & \multicolumn{2}{|c|}{$\overline{\text { Remark }}$} \\
\hline 1 & $\begin{array}{l}\text { The mathematics teacher through his/her teaching of } \\
\text { mathematics developed creative thinking in students }\end{array}$ & 3.71 & 0.48 & \multicolumn{2}{|c|}{ Accepted } \\
\hline 2. & $\begin{array}{l}\text { Students' problem-solving skills are improved upon through } \\
\text { the teaching of mathematics by the mathematics teacher }\end{array}$ & & 3.45 & 0.55 & Accepted \\
\hline 3. & $\begin{array}{l}\text { Communication skills in students were adequately developed } \\
\text { through the teaching of mathematics by mathematics teacher }\end{array}$ & 3.02 & 0.67 & Acce & ted \\
\hline 4. & $\begin{array}{l}\text { Students manage their time very well due to the teaching of } \\
\text { mathematics by the mathematics teacher }\end{array}$ & & 3.18 & 0.67 & Accepted \\
\hline 5. & $\begin{array}{l}\text { Persistency is developed in students through the teaching of } \\
\text { mathematics by the mathematics teacher }\end{array}$ & & 3.16 & 0.54 & Accepted \\
\hline 6. & $\begin{array}{l}\text { Students' organizational skills are properly developed through } \\
\text { the teaching of mathematics by the mathematics teacher }\end{array}$ & & 3.17 & 0.56 & Accepted \\
\hline 7. & $\begin{array}{l}\text { Decision making skills is properly formed in students through } \\
\text { the teaching of mathematics by the mathematics teacher }\end{array}$ & & 3.21 & 0.65 & Accepted \\
\hline 8. & $\begin{array}{l}\text { Students' investigative abilities were properly developed by } \\
\text { the mathematics teacher }\end{array}$ & & 3.15 & 0.71 & Accepted \\
\hline 9. & $\begin{array}{l}\text { Aesthetic skills are developed in students through the teaching } \\
\text { of mathematics by the mathematics teacher }\end{array}$ & & 2.82 & 0.69 & Accepted \\
\hline 10. & $\begin{array}{l}\text { Constructive skills in students are developed by the } \\
\text { mathematics teacher through the teaching of mathematics }\end{array}$ & & 3.30 & 0.75 & Accepted \\
\hline
\end{tabular}

From table 1, it could be observed that the means of the items range from 2.81 to 3.71 respectively, with item 1 having the highest mean and 9 having the lowest. Again, the standard deviation ranges from 0.14 to 0.75 . Item 1 has the least standard deviation while item 10 has the highest. However, all the standard deviation of the items are below 1. The implication of this is that there is closeness of opinion from respondents on the items presented. Furthermore, all the means are above the cut off mean point of 2.50 for decision making. 


\section{Research Question 2}

To what extent do mathematics teachers' methods of teaching mathematics affect the development of entrepreneurial skills in the secondary school students?

Answer to this question is presented in table 2

Table 2.: Mean rating and standard deviation of Mathematics Teacher's method of teaching mathematics and the development of Entrepreneurial skills in secondary school students

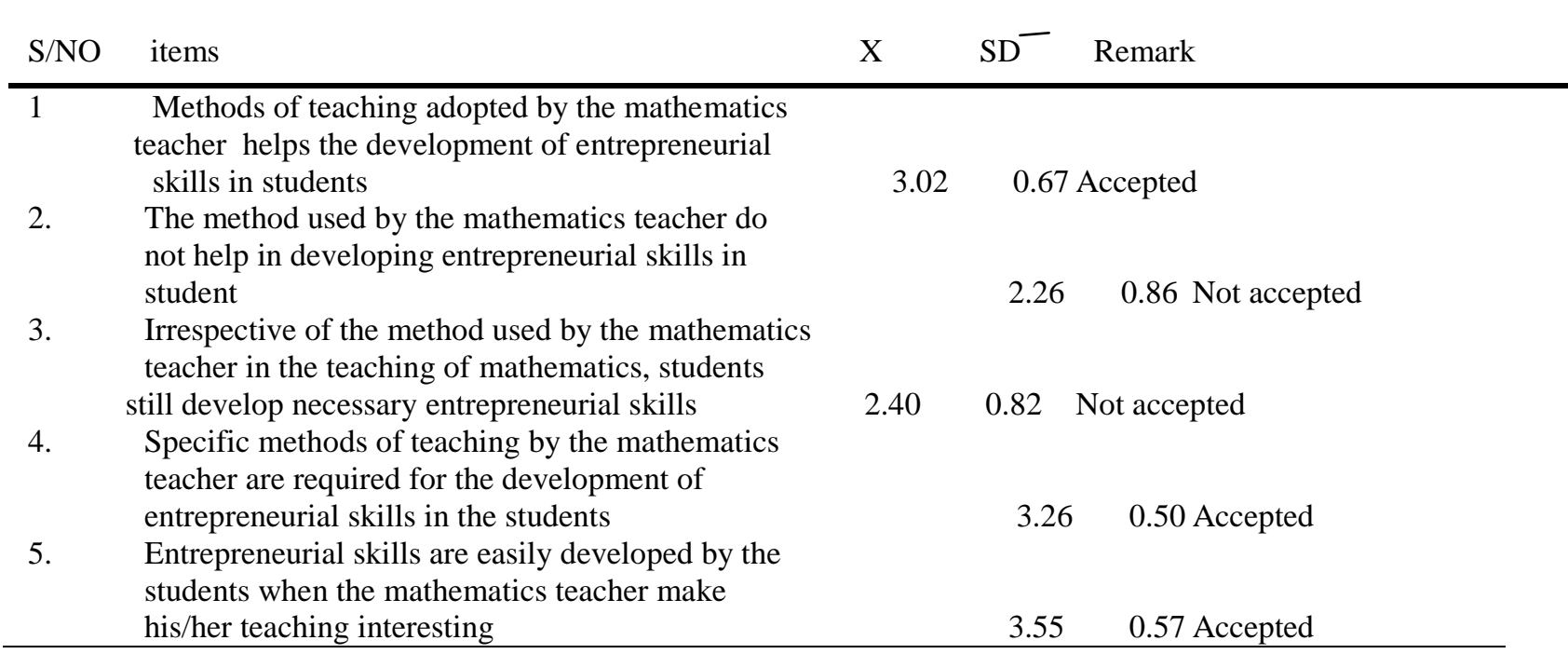

Table 2 showed that the means of items range from 2.26 to 3.55 respectively with item 5 having the highest and item 2 having 2.26 appearing to be the lowest being negatively cued. In the same vain, the standard deviation ranges from 0.50 to 0.86 . Item 4 has the least while item 2 has the highest standard deviation. The implication of this, is that there is closeness of opinion from respondents on the items presented since all the standard deviations of the items are all below one.

Research Question 3

To what extent do the uses of instructional materials by the mathematics teacher affect the development of entrepreneurial skills in secondary school students?

Answer to this research question is presented in table 3

Table 3: Mean rating and Standard Deviation of Entrepreneurial Skills Developed in Secondary School Students due to the use of Instructional Materials by the Mathematics Teacher.

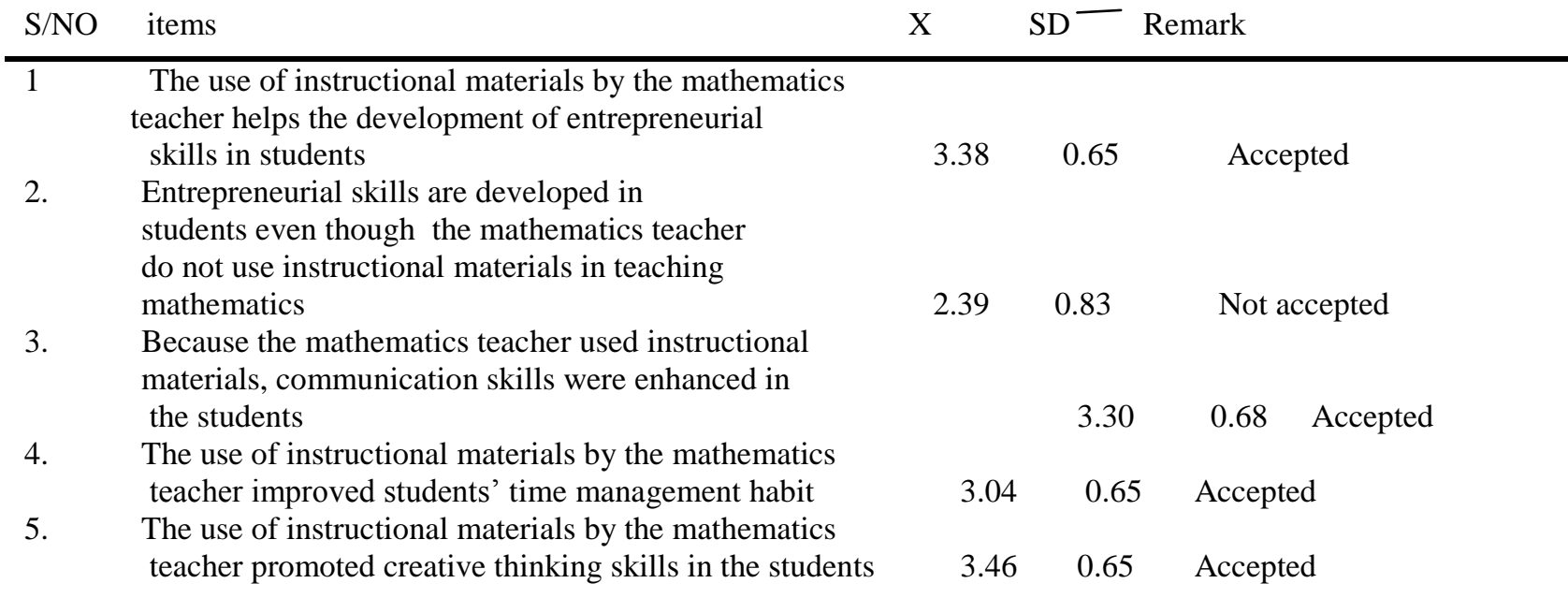


Table 3 indicated that the means of items range from 2.39 to 3.46 respectively. All the items meet up with the accepted decision bench mark. Their corresponding standard deviation ranges from 0.65 to 0.83 . This is quiet below one; hence, there is closeness of opinion from respondents on the items presented.

\section{Research Question 4}

To what extent do mathematics teachers' attitudes to the teaching of mathematics affect the development of entrepreneurial skills in students?

Answer to this research question is presented in table 4

Table 4: Mean rating and Standard Deviation of Mathematics Teachers' attitude and the Development of Entrepreneurial Skills in Secondary School Students.

\begin{tabular}{|c|c|c|c|c|}
\hline $\mathrm{S} / \mathrm{NO}$ & items & $X$ & $\mathrm{SD}^{-}$ & Remark \\
\hline 1 & $\begin{array}{l}\text { Mathematics teachers' attitude to the teaching } \\
\text { of mathematics enhanced decision making skills } \\
\text { in students }\end{array}$ & & 3.08 & 0.67 Accepted \\
\hline 2. & $\begin{array}{l}\text { Mathematics teachers' attitude to the teaching of } \\
\text { mathematics has nothing to do with encouraging } \\
\text { the spirit of persistency in students }\end{array}$ & 2.34 & 0.97 & Accepted \\
\hline 3. & $\begin{array}{l}\text { Investigative skills in students are developed } \\
\text { as a result of the mathematics teachers' attitude } \\
\text { towards the teaching of mathematics }\end{array}$ & & 3.14 & 0.59 Accepted \\
\hline 4. & $\begin{array}{l}\text { The development of aesthetic skills in students } \\
\text { have nothing to do with mathematics teachers' } \\
\text { attitude towards the teaching of mathematics }\end{array}$ & 2.06 & 0.93 & Not accepted \\
\hline 5. & $\begin{array}{l}\text { Students' constructive skills are properly } \\
\text { developed despite the mathematics teacher's } \\
\text { attitude towards the teaching of mathematics. }\end{array}$ & 2.28 & 0.94 & Not accepted \\
\hline
\end{tabular}

Table 4 indicates that the means of items ranges from 2.06 to 3.14. However, it should be observed that items 2 , 4 and 5 are negatively cued. The standard deviation equally ranges from 0.59 to 0.97 . This is an indication that there was a proper closeness of respondents opinion on the issue under consideration.

\section{Summary of major findings}

From the analysis of data presented in this study, the following major findings have been made.

1. The entrepreneurial skills as identified by Houstin \& Muholland (2003) and Tyolumun \& Kwaghfan (2007) could effectively be developed through the teaching of mathematics by the mathematics teacher

2. Methods of teaching adopted by the mathematics teacher in the teaching of mathematics affect the extent to which entrepreneurial skills are developed in secondary school students

3. The utilization of instructional materials by the mathematics teacher in teaching mathematics facilitated the development of entrepreneurial skills in secondary school students.

4. The nature of attitude exhibitated by the mathematics teacher towards the teaching of mathematics has a great consequence to development of entrepreneurial skills in secondary school students.

\section{Discussion of Finding}

Results obtained from this study showed that there exist closeness of opinion from respondents on the issue presented. Means obtained on various items were above the mean cut-off point of 2.5 while their various standard deviations were less than one. This implies that all the respondents were close in agreement and do not differ much in their opinion with regard to the identified entrepreneurial skills that could be developed in secondary school students through the teaching of mathematics by the mathematics teacher. This obviously is in perfect agreement with Houston \& Muholland (2003) and Tyolumun \& Kwaghfan (2007) who identified those entrepreneurial skills that cloud be developed through mathematics education.

Methods of teaching adopted by the practicing mathematics teacher have clearly been shown as very important in accomplishing his/her task. This study showed that, it is an important aid to the development of entrepreneurial skills in secondary school students. This implies that the mathematics teacher has to be very pragmatics in his/her teaching. This outcome tend to be in line with Osafehinti (1990) and Odili (2006) who 
observed that the universally accepted goal of mathematiocs education is to build up understanding of basic mathematics and the development of skills through discovery and practical method of teaching. It is therefore, evident that the methods of teaching adopted by the mathematics teacher will be significant in the process of entrepreneurial skills development in secondary school students.

Again, apart from general method(s) adopted by the mathematics teacher, it was very categorical that the utilization of instructional materials in the mathematics classroom helped greatly to strengthen the development of entrepreneurial skills in secondary school students. This is in harmony with the observation made by Odili (2006) when he stated that unlike physics, chemistry and biology, mathematics instruction have suffered in the past from lack of special facilities and special instructional devices. The implication of this, is that the non- availability or lack of use of instructional materials by the mathematics teacher will have a direct consequence on entrepreneurial skills development in secondary school students.

Having said this, it is fundamental for the mathematics teacher to show a positive attitude towards the teaching of mathematics. This change in attitude is crucial to the dynamic of behavior as well as determines how effectively a teacher teaches and the extent to which entrepreneurial skills could be developed in secondary school students. That is why Samo (1984) opine that no meaningful lesson can take place under a harsh teacher.

\section{Recommendations}

Base on the findings of this study, the following recommendation are made.

1. Since it is obvious that there are shortage of instructional materials in secondary schools, mathematics teachers should make concerted effort to improvise them.

2. Mathematics teachers in secondary schools should be up -to- date with different methods of teaching the subject. To achieve this, secondary schools in Makurdi should be provided with good mathematics books that highlight efficient methods of teaching mathematics. A re-training programme, workshops and seminars should be organized for these teachers where issues such as effective teaching methods are handled

3. The mathematics teacher should learn to keep his/her temperament in check; entertain questions without shouting or mocking the students for asking 'stupid' questions.

\section{Conclusion}

It is evident that the identified entrepreneurial skills remain the skills that could be developed in secondary school students by the mathematics teacher through the teaching of mathematics. However, factors such as methods employed by the mathematics teacher in the teaching of mathematics, the use of instructional materials by the mathematics teacher as well as his/her attitude towards the teaching of mathematics have direct influence on the development of entrepreneurial skills in secondary school students in Makurdi metropolice of Benue State, Nigeria.

\section{References}

[1]. Aminu, J.(1995). Quality and stress in Nigeria education Kaduna. Northern Nigerian publishing company

[2]. Federal Republic of Nigeria (2004). National policy in education. Ikeja: NERDC

[3]. Houston, K. \& Muholland, G. (2003). Entrepreneurial Mathematics graduate. Downloaded from http://www.math.uoc.gr on 28/2/12

[4]. Nickels, W. G. \& Mchugh, J. M.(2002). Understanding business $\left(6^{\text {th }}\right.$ ed). New York: McGraw Hill.

[5]. Odili, G. A. (2006). Mathematics in Nigeria secondary schools: A teaching perspective. PortHarcourt: Rex Charles and practice limited.

[6]. Osafehinti, I. O.(1990). The university of mathematics. Journal of mathematical association of Nigeria 20(1), $48-56$

[7]. Samo, D. A.(1984). Mathematics Method Ibadan: Abi print and part limited

[8]. Tyolumun \& Kwaghfan, A.E.(2007). Basic management and entrepreneurial skills. Makurdi: Traces Nigeria limited. 